\title{
DAO INTELLIGENCE AND DAO LEADER WELL-BEING
}

\author{
Dilin Yao \\ Shanghai Maritime University, P.R.China \\ Jun Chen \\ Shanghai University, P.R.China
}

\begin{abstract}
Chinese traditional philosophy can offer a rich source of insight for current leadership studies. The aim of this article is to discuss two main aspects of Dao philosophy, Dao intelligence and Dao leader well-being. The article makes two contributions to knowledge. First, it outlines a conceptual model of Dao intelligence from six aspects based on Dao philosophy in Dao De Jing. Second, it provides a model of Dao leader well-being based on Dao intelligence. It is argued that Dao intelligence offers new opportunities for leadership research and practice. The article concludes with a discussion of the practical value of considering Dao philosophy as an underlying approach to leader intelligence and leader well-being.
\end{abstract}

Key words: Dao De Jing, Dao intelligence, Dao leader, Well-being

JEL code: M190

\begin{abstract}
Dao philosophy arising from the book of Dao De Jing is the foundation of this article. Laozi is the author of Dao De Jing. Laozi is a great ancient Chinese philosopher, born approximately 2500 years ago. Dao De Jing consists of two parts: Dao Jing and De Jing with five thousand words. Laozi identified Dao as the essence of the universe and the nature of all things in the earth. In the modern society, we could gain wisdom from Dao in the attempt to pursue the root cause of all tangible phenomena in life, including the scientific theories and practices. Thus, Dao De Jing is a book with the essential Dao philosophy that has implications for contemporary leadership theory and practice. Dao philosophy is presented in this research as a philosophical and wise pattern of leadership intelligence and well-being.

The purpose of this article is to elaborate Dao intelligence and Dao leader well-being based on Dao philosophy, drawing on the essential leadership-related content from the 81 chapters of the Dao De Jing. This paper's discussions of the relevant chapters (which have been translated by the author) rely on mainstream interpretations of the Dao De Jing (Yao and Gan, 2013). The specific notion illustrated in this paper is Dao intelligence with the purpose to make essential contributions to knowledge: First, it outlines a conceptual model of Dao intelligence from six aspects based on the Chinese traditional Dao philosophy. Second, it provides a model of Dao leader well-being based on Dao intelligence. This paper has three
\end{abstract}


sections. First, Dao philosophy is introduced. Then, a Dao intelligence model based on Dao philosophy is constructed. Third, a Dao leader well-being model is constructed based on Dao intelligence. Fourth, a business case applying Dao philosophy and Dao intelligence to operate its company is introduced, and implications for practice of Daoistic management with Dao intelligence are stated. Finally, the paper concludes with a discussion of the value of considering Dao philosophy in relation to leadership intelligence and well-being.

\section{Dao Philosophy}

Dao is mysterious and difficult to be explained explicitly (Ma and Tsui, 2015). In the first Chapter, Laozi illustrated Dao as the foundation to build up the whole ideas of his book. Dao is intangible without form or image, and cannot be seen by the eyes, heard by the ears, or touched by the physical body. Dao represents the truth that pre-existed before myriad of things in the universe were created. It represents the energy of the void that permeates the tangible and intangible world as well. Chapter 14 stated that it is not the same with the phenomenal world. If one side is bright, the other side is dark. If the top is bright, the bottom is dark. On the contrary, the profound essence of Dao is different. It is not bright on the top and it is not dark on the bottom. Dao permeates Heaven and Earth in the Cosmos unceasingly. Dao seems to take on a physical form but it is difficult to discern. Dao is the ultimate void. It is the formless "form" and the intangible "object". This is why people describe the essence of Dao as indiscernible. It seems to exist and it also seems to be non-existent. The Chinese word Dao (道) is the universal law (Jing and Van de Ven, 2014). As a result, people must follow the rule of Dao (Ma and Tsui, 2015; Lee et al., 2008). The following sections would construct Dao intelligence model and Dao leader well-being model based on Dao philosophy.

\section{Constructing a Dao Intelligence Model}

Intelligence was defined as "the ability to solve problems, or to fashion products, that are valued in one or more cultural or community settings" (Gardner, 1993, p.7). Gottfredson (1997) presented that intelligence is a general mental ability including solving problems, thinking creatively, learning capability, deep comprehension, etc. This paper will offer Dao intelligence based on Dao philosophy, as Chapter 38 in Dao De Jing stated that the great Dao is most tranquil and it embraces non-action. It is also the only, absolute One. Dao is also regarded as the Oneness. It is man's original nature. From the ancient times until now, Heaven is clear and bright when it upholds the Oneness. Earth will become calm and serene when it upholds the Oneness. Deities will become profound and sensitive when they uphold the Oneness. When men uphold the Oneness, they will be understanding and tranquil. When a valley upholds the Oneness, it will become complete and fulfilled. Myriad of things will be able to grow when they uphold the Oneness. An emperor will become stable and content when he upholds the Oneness. Everything in the world is interconnected with one another and everything can accomplish themselves in Dao. Therefore, the study of the "Dao" is the most profound among all schools of knowledge. Dao offers intelligence that is named Dao intelligence in this paper. 
Dao intelligence is the basic intelligence from which certain skills, capacities, and competencies arise based on Dao philosophy in Dao De Jing. It is distinct from traditional mental ability. Laozi described this intelligence in Chapter 47 that there is an absolute principle in the world. The saints are able to understand this principle. This is why they are able to understand everything without having to step outside of their homes. Following the rule of Dao, six aspects of Dao intelligence (Figure 1) would be constructed and described as follows:

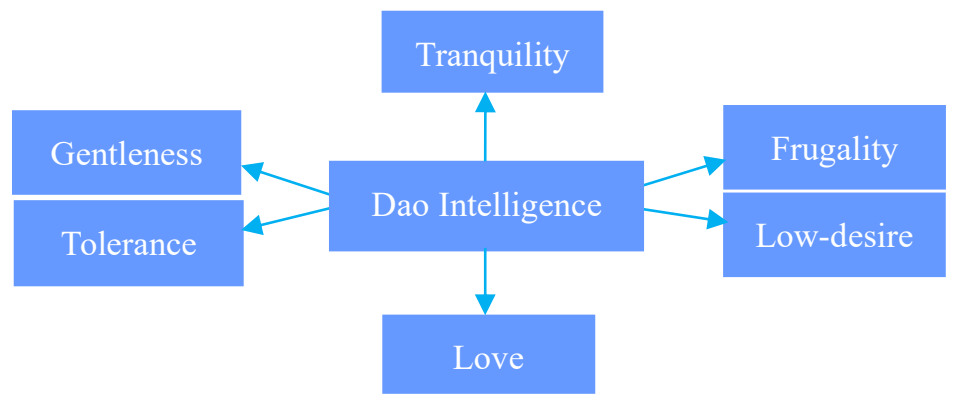

Figure 1. Construction of Dao Intelligence Model

\section{Tranquility}

Chapter 16 stated that there are myriad of things, but they all have to return to the origin which is the meaning of tranquility. As Chapter 40 presented that even though all myriad of things revolve over and over again, they will have to eventually return to the state of calmness. Chapter 45 indicated that the brilliant original nature of tranquility is the origin of all changes. It is similar to the phenomenon of changes with horrendous rain and wind. The sky remains clear after the rain has stopped and the air remains calm after the wind has subsided. The goal that everyone should strive for is the tranquil original nature. It is only through this original nature that everything is able to reside in its proper position. Then, peace and harmony in the world are achieved naturally. Chapter 11 stated that the intangible true nature is the one that operates the physical body. We need to learn from Dao and return to our tranquil true nature (Chapter 10).

Chapter 26 indicated that the foundation which stabilizes one's compulsive behavior is a calm true nature. Therefore, the saints constantly adhered to their stable and calm true nature. A noble person with Dao emphasizes the importance of maintaining a calm mind (Chapter 30 and 31). A person's virtue will only be perfected if he diligently cultivates himself (Chapter 54). Our virtue will be very deep if we regard accumulating virtue as necessary as repeatedly getting dressed in the morning (Chapter 59). A person with deep and profound virtue is like an innocent child (Chapter 55). In this way, external images, praises and insults will not be able to disrupt the tranquility of your original heart (Chapter 56). You will be the most revered person in the world. As Chapter 28 stated that a saint who is capable of great accomplishments would rather maintain his pure and tranquil true nature. 
Chapter 61 presented that female animals in this world are able to conquer stronger male animals with tenderness and tranquility. Although tranquility and stillness appear insignificant, it becomes the underlying principle in conquering restless brute force. Chapter 57 presented that people will maintain propriety as long as the ruler remains humble and tranquil, does not act on impulse or indulge in gratification. Chapter 60 indicated that to govern a large country is like frying many little fish. One should not stir too often or the little fish will crumble. People will find it difficult to adapt and greatly troubled if government changes its policy too frequently. A ruler should maintain a calm mind with few desires and live a simple life style in tranquility (Chapter 75). Thus, people would live a simple lifestyle of harmony with contentment, and there will not be any desire to move anywhere else (Chapter 80).

\section{Gentleness}

Chapter 8 stated that these are the wonderful functions of water. The motion of water is most natural. When water flows to a round space, it morphs into a round shape. When water flows to a square space, it morphs into a square shape. In humid weather, it comes down as rain. In sunny weather, it evaporates and rises. Chapter 43 indicated that the gentlest thing on Earth is water. However, even though water is gentle and soft, it penetrates mountains and earth. Even though gas is invisible, it upholds all various planets. These invisible, soft energies are usually stronger than physical objects with form. Even though water is most gentle of all things, it always claims the final victory when it is attacked by anything strong (Chapter 78).

Chapter 36 presented that never underestimate anyone who appears to be meek and mild on the outside. Only those who appear to be meek and mild can overcome those who appear to be strong and rigid. When the saints were handling matters in life, they always remained humble and mild. This is how the saints are remembered. Chapter 49 stated that the mind of a saint is flexible and is able to adjust according to the attitudes and traditions of the people. He never imposes his own ideas onto others nor discriminates against anyone. As Chapter 58 indicated that only the saints, who are without sharp edges to hurt others, are able to maintain integrity and propriety. They are proper and upright in character, but treat others with an honest and tender heart. The saints will not punish others severely or treat anyone harshly. The saints are honest and upright, but never overly straightforward. Those who remain soft are the ones who receive respect and support from others (Chapter 76).

\section{Tolerance}

Chapter 2 stated that after the saints realized this phenomenon of relativity, they were able to uphold their original nature and handle their affairs with the perspective of "non-action" (letting things take their own course). As Chapter 4 indicated that the nature of Dao is intangible and encompassing. It never presents itself in a high profile. This attribute demonstrates that Dao is never competitive or in confrontation with all myriad of things. Instead, Dao is ever generous and tolerant in solving conflicts. It exists wherever there is brightness. It exists wherever there is dust. The ancients stated that endurance of grievance is a complete virtue (Chapter 22). Endurance and tolerance is a process to overcome oneself. Only one who is able to overcome himself can be considered the strongest person (Chapter 
$33)$.

Chapter 42 stated that one may seem to be deprived on the surface, but he actually gains in the end. On the contrary, one may seem to have gained on the surface, but he actually loses out in the end. Thus, to be tolerant, to be gained. Chapter 45 presented that a truly upright person is able to tolerate everything. On the surface, he may appear to have received injustice from others. Chapter 66 indicated that the reason a vast ocean becomes the ultimate destination of numerous rivers is in the ocean's ability to adapt itself to a place of lowest position. In a lowest position, an ocean is able to accommodate water, whether it is clean or dirty, from numerous rivers. This is why a vast ocean is the ultimate destination of numerous rivers. To be tolerant is to be like a vast ocean.

\section{Low desire}

Chapter 32 indicated the term "simplicity" describes the appearance of heaven and earth before they were created. Chapter 35 stated that no one should indulge in enjoyment even though peace and harmony have been restored. Enjoyment is as brief as the passage of a visitor. It does not last forever. Only our true nature, which is the manifestation of Dao, is as eternal as the void. Dao is so plain and simple. The saints only look for ways to realize their nature and do not cherish fame and prestige of the phenomenal self or the shallow, lustful emotions of the human world (Chapter 72). As Chapter 46 stated that a person who realizes his true nature is perfectly self-sufficient and is a content person who succeeds in everything. Since he does not seek anything external, he is able to attain the treasure of his inherent true nature. Chapter 44 indicated that a content person who minimizes his desires will not cause his virtue to be incomplete. Naturally, he can transcend to a state of no-worry and distant himself from shame and insult.

Dao cultivators of the past were not attached with external affinity (Chapter 15). Laozi in Chapter 20 stated that his heart is contented and calm; it is as deep and wide as the ocean. It is also as free as the wind, without attaching to any one place. Chapter 25 presented that the last step in cultivating Dao is to emulate the natural non-action state of Dao. In practice, it means not taking credit even though you may have benefited everyone. As Chapter 34 stated that the great Dao is without desires and does not claim any credits. The emperor should not claim recognition when the country is successfully governed (Chapter 17). Arrogance is a disease (Chapter 71). Human beings must behave appropriately (Chapter 9 and Chapter 24). Chapter 30 indicated that everything in the world follows the course of nature. Everything progresses along the stages of development, maturity, old age and ultimately death. With this understanding, one should get rid of all intentions to compare, to conquer and to fight. One must uphold a pure and innocent heart, maintain selflessness without desires, and restore one's purest and most genuine original nature (Chapter 19).

\section{Frugality}

Chapter 12 stated that the saints are aware of the pitfalls of materialistic desires. This is why 
they do not indulge in materialistic enjoyment. Instead, the saints focus whole-heartedly in nourishing their nature and resisting the distraction of external phenomena. Chapter 48 stated that for anyone to learn Dao, one has to rid himself of sensual desires and improper thoughts. Hence, he who devotes himself to the Dao will diminish his wrongdoing day by day. In addition, one should also shed the attachments of superficial human relationships, as well as fame and wealth. A person is able to accomplish his original nature of nonaction when he is selfless without materialistic attachments. Ordinary people crave for valuable material possessions but the saints look for ways to restore their original nature and remind sentient beings not to behave deviously and betray one's own conscience (Chapter 64).

Frugality is both on material and spiritual perspectives. Chapter 5 indicated that instead of engaging in the kind of unnecessary behavior, it is better to maintain the principle of upholding the center. Getting rid of emotional troubles, step into the orbit of Dao. Chapter 3 indicated that if everyone focuses on the non-action aspect of our original nature in governing the world, the world can be governed well. Chapter 65 presented that in the past, a ruler who governed with the great Dao never taught his people to be conniving. Instead, he taught his people to be pure and honest. It is because when the people are conniving, it would be difficult for the country to be governed. Everyone will end up getting hurt and there will be chaos in the country. On the other hand, if rulers of a country are not scheming, the heart of everyone will naturally be pure and everyone will live in peace and harmony. This is indeed a good fortune of the country.

\section{Love}

Dao is the origin of all things (Chapter 6 and 52). However, Chapter 50 stated even though Dao is the master of all things, it never regards itself as master. Dao is never possessive even though it provides tremendous blessings to everything with nourishment and protection. Indeed, Dao possesses the most profound and ultimate virtue. Only the virtue of Dao is most admirable, because Dao nourishes all myriad of things indiscriminately (Chapter 79). We should learn from the virtue of Dao with a heart of selfless love. As Chapter 13 stated that a person who leads a life of Dao will not regard being in a prestigious position as personal glory. He will regard his personal prestige as everyone's prestige. He will regard personal glory as everyone's glory. Only this kind of person with Dao can be entrusted with governing the world. If there is a person who values his body for the great mission of saving the world instead of indulging in luxury and wealth, then this kind of person can also be trusted with governing the world. People suffer greatly under a tyrannical ruler who suppresses his people (Chapter 74). As Chapter 69 presented that people who are fond of killing and fighting are the main reason calamities take place.

A saint's virtue with Dao love always places others ahead of himself (Chapter 7 and 81). Virtuous people with Dao love use their merciful hearts to console someone who is in despair and can bring happiness to everyone (Chapter 23). A truly virtuous person with a kind and loving heart will not take credit even after he has performed many great deeds (Chapter 37). An official with Dao love always cares for his subordinates (Chapter 68). Chapter 77 
indicated that the way the Dao treats myriad of things is highly disciplined and complimentary in nature. It will use whatever is in surplus to compensate what is lacking. Dao guides those who are in a high position to assist those who are in a low position. Thus, Dao balances all things. This is the way in accordance with the love of harmonious Dao without discriminating heart (Chapter 39). It is impossible for any selfish person to be truly successful in capturing the world (Chapter 29).

Summarily, Laozi in Chapter 67 taught three essentials regarding cultivating oneself and handling affairs in accordance with Dao intelligence. Firstly, one must maintain a merciful and loving heart. Secondly, be frugal, honest and simple. Lastly, never be egotistical, arrogant and boastful. The cultivation of Dao intelligence needs to be improved by constant reflection. As the saint is always cautious in his approach and reflects upon himself constantly (Chapter 63).

\section{Levels of Being and Dao Leaders}

Fry and Kriger (2009) developed being-centered leadership theory and identified five levels of being, from the most concrete level (Level V) to more abstract Levels (Level IV, III, II, I) (Figure 2). Rather than current leadership theories which focuses on having proper capabilities and behaviors, the multi-level model of being attempts to remove the duality between leaders and followers, tangible and intangible worldviews in leadership. The five levels and the most salient types of leadership at each level will be introduced according to the statement of Fry and Kriger (2009) as follows:

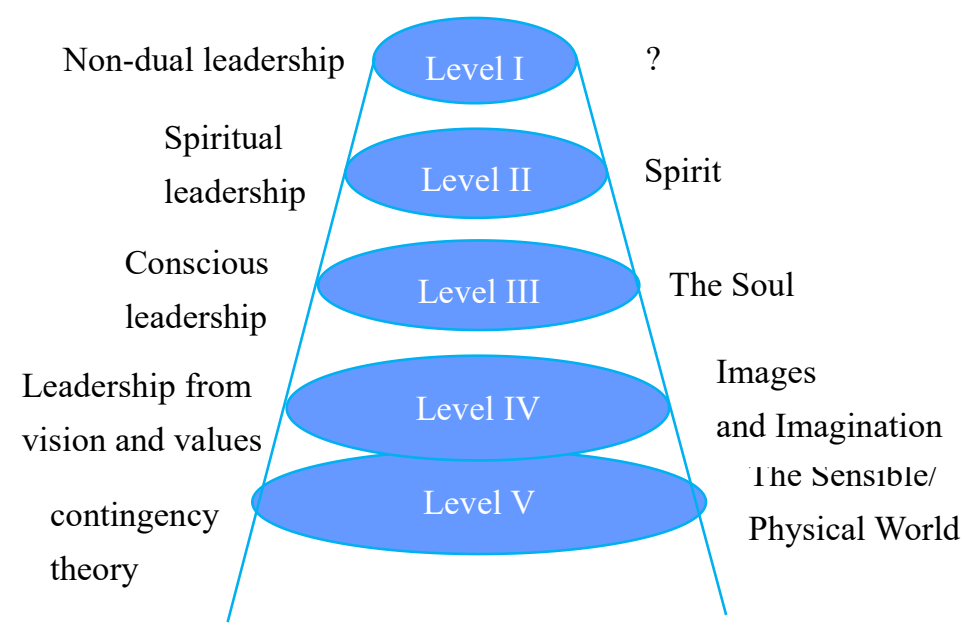

Figure 2. Multiple levels of being and leadership (Fry and Kriger, 2009)

The fifth level of being is the sensible and physical level in the observable world, which is the most current leadership theories and researches focus on. The corresponding leadership approaches include: 1) Traits or distinguishing personalities of effective leaders like optimistic, self-confident, and the pursuit of excellence (Bass, 1990); 2) Behavior, and 
contingency theories to adopt leadership behaviors which are appropriate for subordinate characteristics and the organizational situations to produce an expected organizational outcome (Yukl, 2006). The phenomenal indicator to measure the effectiveness of leadership in this level are sales growth, profit growth, return of assets (ROA) and return on equity (ROE).

The fourth level of being focuses on images and imagination. At this level leadership energizes followers by providing images and imagination to work for the sense of meaning and an ideal direction to increase organizational commitment and performance. The corresponding kinds of leadership theories in this level include: 1) Transformational leadership, which is characterized by offering a future vision and a sense of meaning to subordinates striving for the significant change of themselves and organizations (Tichy and Devanna, 1986). Inevitably, some transformational leaders inspire followers with features of charismatic leadership; and 2) Charismatic leadership, which ignites subordinates' energy and organizational commitment (Kleinand and House, 1995). Charismatic leaders display strong confidence, positive energy, exceptional strength and personal attributes to lead to subordinates' trust identification and emotional involvement with leaders by offering imaginative vision and images of a future blueprint.

The third level of being is the soul level. The soul is the individual self. To understand the soul is to go beyond ego-centered self, including the body, temperament, emotions, etc., and be aware of the present, true and bright self. The awakening to awareness of soul is important for leaders to be more other-centered and compassionately perceive the needs of subordinates and the changing situations. Leadership theories in this level include: 1) Authentic leadership, authentic leaders foster self-awareness of leaders and subordinates, and promote genuine and trusting relationships (Avolio and Gardner, 2005). Authentic leaders to some extent facilitate the positive and ethical cultures in organizations; and 2) Ethical leadership, the antecedents and outcomes of ethical leadership was investigated (Brown and Trevino, 2006).

The second level of being is spirit level. Spirit is the living strength in every human being. The focus of leadership in this level displays altruistic love and service to empower followers intrinsically. However, very few recognized leaders operate consistently at this level. Current leadership theories that nourish spirit include: 1) Servant leadership, through the way of personal interacting with followers, servant leaders acquire subordinates' information, then accordingly to help them developing their potentials and build a long-term trustworthy relationship with employees and multiple stakeholders (Liden et al., 2008); 2) Spiritual leadership theory (Fry, 2003, 2005, 2008), was developed based on the intrinsic motivation model to satisfy fundamental needs for spiritual well-being through the dimensions of calling and membership, which positively influences employee well-being, sustainability and corporate social responsibility, and financial performance.

The first level of being is the most inclusive oneness level of being as the non-dual. The non-dual involves a transcendent unity beyond contradiction and distinctions, including both pure emptiness and pure fullness. From the non-dual level of being, duality and separation 
will dissolve. Thus, leaders in the non-dual level would manifest unconditional regards for others, intuit the needs of others quickly and facilitate equality between leaders and subordinates. Fry and Kriger (2009) identified the non-dual variable as '?' which varies depending on the names as adopted in the respective religious traditions of Judaism, Christianity, Islam, Hinduism, Buddhism and Daoism. From the perspective of traditional Daoism, Fry and Kriger (2009) referred "?" as "Dao" at the first non-dual level of being. Laozi is the founder of the Daoist school and a great ancient Chinese philosopher as well. Dao De Jing is a philosophical book about leadership and management rooted in Dao philosophy that offers instructions for contemporary leadership theory and practice.

Thus, based on the being-centered leadership theory and essences in Dao De Jing to define Dao leaders who conduct Dao behaviors through Dao intelligence by the cultivating journey of going inward to find inner Dao, a natural self-awareness and perceptions, as a source of strength to love and serve others to achieve the Dao altruistic level leadership and lead their subordinates to pursue the life of well-being. As the non-dual level of being is to be achieved through both endogenous to the inner perception of leader and exogenous to the external environment, and the non-dual level provides a vision of what leadership can become at the highest level (Fry and Kriger, 2009). The following sections would be rooted in Dao philosophy and Dao intelligence to demonstrate the process of the construction of Dao leadership well-being from the inner perception and external outcome with a vision of the highest level of Dao.

\section{Constructing a Dao Leader Well-being Model Based on Dao Intelligence}

Dao leader well-being (Figure 3) arises from the Dao intelligence cultivation that the leader inner Dao resonate with the outer Dao philosophy and employee inner Dao to help leaders and employees find the Dao belonging and motivate the leaders' and employees' noble pursuit to produce the higher level of behavior and well-being.

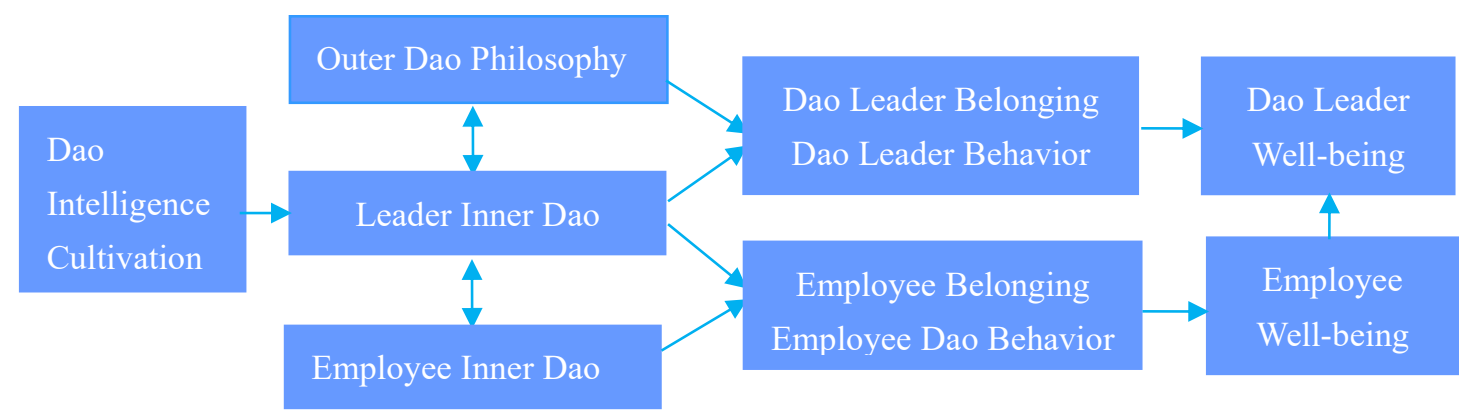

Figure 3. Construction of Dao Leader Well-being Model

\section{Dao belonging and well-being}

Chapter 21 indicated that the essence of Dao is formless, nameless and indiscernible. Even though the essence of Dao is indiscernible, it is complete with everything including Heaven and Earth. It is eternal, profound and contains the origin of life. It is invisible but consists of 
real elements and principles. Within these elements, one can find the evidence of the elements' functions and the basis of their everlasting evolution. Dao exists perpetually from the ancient times until now. Due to the continual existence of the true nature, people in the world are able to give evidence of its presence and appreciate it. Chapter 41 continued that we are not able to hear the sound of the revolving planetary objects even though it is very loud. We are not able to see the form of the eternal truth even though it is infinitely large. This shows the obscurity of Dao which does not even have a name. Therefore, people on Earth are not aware of the assistance from Dao which exerts tremendous energy in nourishing and accomplishing myriad of things.

Chapter 51 presented that Dao is the mother of all things. Everything originates from the essence of Dao. Dao nurtures everything so that they are able to grow and mature. The nourishment and nurturing from Dao is everlasting. Dao is never possessive even though it provides tremendous blessings to everything with nourishment and protection. Dao is never boastful of its strength in accomplishing these great deeds. Even though Dao is the master of all things, it never regards itself as master. Thus, each of us possesses the most profound and ultimate virtue of Dao. Dao intelligence cultivation helps leaders and employees to return to their original nature of Dao which can resonate with each other and follow the outer Dao philosophy to find the sense of Dao belonging. This is the higher level of spiritual well-being.

\section{Dao behavior and well-being}

Dao intelligence cultivation will motivate leaders and employees to pursue noble Dao behaviors. Chapter 27 indicated that a person with utmost virtue does not leave behind even a trace of his own good deeds in his heart. He does not behave hypocritically and show off his great intentions when he is doing good deeds to benefit the world. A person with utmost virtue speaks only the truth since his speech is a natural manifestation of his own original nature. He is able to easily convince others because he does not have any shortcomings. Chapter 62 stated that why did the saints in the past adhere to the most precious Dao? Their goal was to practice the great Dao constantly. They realized to behave otherwise was contradictory to Dao. A person will create sins when he acts contradictory to Dao. A person will inevitably be punished if he has sinned. From the above, one can conclude that Dao is the most precious of all. Nothing can escape from the net of karmic retribution (Chapter 73). Thus, Dao noble behaviors are the guarantee of Dao leader and employee well-being. Employees' well-being is one indicator of leaders' success which will lead to leaders' well-being.

Summarily, Laozi in Chapter 53 presented that originally the path of the great Dao is very smooth and wide. Unfortunately, some greedy people always like to look for shortcuts. Regrettably, those who take shortcuts will only harm themselves in the end. In Chapter 70 Laozi indicated that his opinion is very simple and understandable. People are not able to understand and follow because their nature has been deluded. His opinion is based on a great principle and there is deeper meaning in everything. However, people are not able to understand the principle or the meaning in his words. It is because of the prolonged negative influence people have received from the external environment. Only a very small number of 
people are able to truly understand precious Dao. Thus, it is necessary to return to the precious Dao value.

\section{Application and Implication}

\section{A case related to Daoistic management with Dao intelligence}

According to the twenty-second edition of "Global Times" on April 2, 2003, after practicing Daoistic management, the profit of a company in Britain surged 200\% full of new vitality with impressive performance (Ren, 2003). This event caught a number of major British media attention. Farrelly equipment engineering company is a family corporation which was built for more than ten years only with mediocre performance. A few years ago, the boss's brother Jerry read "Dao De Jing". The book advocated benevolence and harmony of management which brought inspiration to him. Jerry felt that only let employees feel happy, we can fully arouse their enthusiasm and creativity. He suggested to apply the philosophy of "Dao" and "love" into the management to attract talents, retain talents, and cultivate team spirit.

The management policies with Dao intelligence are implemented in Farrelly as follows: 1) The first thing at work is to shake hands and hug with a good start which contribute to employee morale. Of course, never force staff, but employees seem to be quickly adapted to this new "rule". Employees spontaneously embrace each other; 2) The company has a special stipulation is to give employees a day off in their birthday. Staff birthday holiday is a concrete manifestation of the company's people-oriented business philosophy; 3) Employees never work overtime, because the company emphasizes team spirit, advocating cooperation and mutual help. Usually, a clerk who has finished his work will take the initiative to help other colleagues. If one staff cannot finish his task, other people will help him, then leaving the office together; 4) The office also plays relaxing music. Colleagues will go to the club drinking and chatting on the weekend; 5) In each month, the company holds dinner parties. Through regular parties, the company greatly strengthen the communication between employees, solve some internal conflicts in time, and make employees more united.

Does such relaxed working environment not affect the work efficiency? An officer in charge of training considered that creating such environment can greatly improve work efficiency, the wellbeing and performance of employees and leaders. Employees love this culture. In Farrelly, employees feel that they are moving in the same direction. Employees said that even if other companies offer higher wages they are not willing to quit work here because Farrelly improves their quality of life. These measures in Farrelly are not profound. However, the company's profits began to rise sharply after the implementation of Daoistic management, not only developing new customers, but also getting various awards and honors from industry associations and government. All of these achievements should attribute to the "people-oriented" Daoistic management, which would definitely bring well-being to leaders with Dao.

\section{Implications for practice of Daoistic management with Dao intelligence}


From the above case, two implications for the practice of Daoistic management are stated here: First, the management with Dao intelligence would help achieving business success. Dao intelligence management emphasizes that staff is the foundation of an enterprise. Without foundation, senior management does not exist. Thus, leaders should pay attention to every employee, putting employees' needs in the first place. Then, employees will work hard to improve work efficiency, develop the company, and ultimately benefit the operators. Second, Dao intelligence management would bring wellbeing and happiness to leaders with Dao. As Lee et al. (2008) stated that Daoism may assist managers to lead more joyfully and effectively in the practice. Eastern management philosophy (e.g. Daoism) may complement with western management philosophy to help leaders manage more satisfactorily and effectively.

\section{Conclusion: The Value of Considering Dao philosophy for this Research}

The article constructs a Dao intelligence model from six aspects based on the Chinese traditional philosophy in Dao De Jing. Based on Dao intelligence, this paper provides a model of Dao leader well-being. Dao intelligence offers a new paradigm for leadership research and help researchers and practitioners better understand leadership from unique Dao philosophy. The whole article is based on Dao philosophy. Chapter 18 presented that the preciousness of benevolence and righteousness is most obvious when it is difficult for the great Dao to be manifested in the world. On the contrary, benevolence and righteousness are most obscured when the great Dao is prevalent. During which time, people may not even know the meaning of benevolence and righteousness. In the ancient times when the great Dao was prevalent, everyone was pure and lived in accordance with the will of heaven. However, in the middle ages, it became more and more difficult for the Dao to be manifested. What is the value for this research to consider Dao philosophy on leadership intelligence and well-being?

First, Dao is the intangible origin of the universe. Dao as the successful living philosophy offers significant instructions to guide the world. However, in the modern society, people pay more attention to tangible issues and Dao is being forgotten gradually by people. As a result, we need to return to the origin of the universal law and gain wisdom from Dao in the attempt to pursue the root cause of all tangible phenomena including leadership research to rethink about leadership intelligence and well-being.

Second, we currently live in the area of uncertainty, volatility, change and ambiguity. Well-being is becoming a popular topic. With the root nature of Dao in human being, we need to integrate humanistic concern from the aspect of recognizing and respecting human Dao nature with leadership research and practice. Through the way of Dao intelligence to improve the spiritual level continually, stay synchronized with the universal will Dao and return to Dao well-being.

The original texts in Dao De Jing eighty-one chapters are used to present leaders with specific Dao intelligence of Dao leadership to help attaining both leaders' and employees' well-being. This article forms the basis for related research interested in a combination of eastern wisdom 
and philosophy with contemporary leadership knowledge. As Dao De Jing and Dao philosophy is a valuable heritage that Laozi left with the world, the future study may further develop specific Dao approach to guide leadership theory and practice.

\section{References}

Avolio, B. J. and Gardner, W. L. (2005) "Authentic leadership development: Getting to the root of positive leadership development", The Leadership Quarterly, vol. 16, no.3, pp. $315-338$.

Bass, B. M. (1990) Handbook of leadership: Theory, research, and managerial implications $\left(3^{\text {rd }}\right.$ edn), New York: The Free Press.

Brown, M. E. and Trevino, L. K. (2006) "Ethical leadership: A review and future directions", The Leadership Quarterly, vol.17, no.6, pp. 595-616.

Fry, L.W. (2003) “Toward a theory of spiritual leadership”, The Leadership Quarterly, vol.14, no.3, pp. 693-727.

Fry, L. W. (2005) "Toward a theory of ethical and spiritual well-being, and corporate social responsibility through spiritual leadership", in Giacalone, R. A., Jurkiewicz, C. L. and Dunn, C. (eds.) Positive psychology in business ethics and corporate responsibility, Greenwich, CT: Information Age Publishing.

Fry, L. W. (2008) "Spiritual leadership: State-of-the art and implications for theory, research, and practice", in Biberman, J. and Tishman, L. (eds.) Spirituality in business: Theory, practice, and future directions, New York: Palgrave.

Fry, L.W. and Kriger, M. (2009) "Towards a theory of being-centered leadership: Multiple levels of being as context for effective leadership", Human Relations, vol.62, no.11, pp.1667-1696.

Gardner, H. (1993) Multiple lntelligences: The Theory in Practice, New York: Basic Books.

Gottfredson, L. S. (1997) "Mainstream science on intelligence: An editorial with 52 signatories, history and bibliography”, Intelligence, vol.24, no.1, pp.13-23.

Jing, R. and Van de Ven, A. H. (2014) "A Yin-Yang Model of Organizational Change: The Case of Chengdu Bus Group", Management and Organization Review, vol.10, no.1, pp. 29-54.

Klein, K. J. and House, R. J. (1995) "On fire: Charismatic leadership and levels of analysis", The Leadership Quarterly, vol. 6, no. 2, pp. 183-198. 
Lee, Y.-T., Han, A. G., Bryron, T. K. and Fan, H. X. (2008) "Daoist leadership: Theory and application", in Chen, C. C. and Lee, Y.-T. (eds.) Leadership and management in China: Philosophies, theories and practices, New York, NY: Cambridge University Press.

Liden, R. C., Wayne, S. J., Zhao, H. and Henderson, D. (2008) "Servant leadership: Development of a multidimensional measure and multi-level assessment", The Leadership Quarterly, vol. 19, no.2, pp. 161-177.

Ma, L. and Tsui, A. S. (2015) "Traditional Chinese philosophies and contemporary leadership", The Leadership Quarterly, vol. 26, no.1, pp. 13-24.

Ren, T. (2003) "People-oriented management: Dao De Jing changes the British company", [Online], Available: http://www.people.com.cn/GB/guoji/25/95/20030404/963273.html?54a4e [12 July 2017].

Tichy, N. M. \& Devanna, M. A. (1986) The transformational leader, New York: Wiley.

Yao, D. \& Gan, S. (2013) Dao De Jing and Leadership, Beijing: Economic management press.

Yukl, G. A. (2006) Leadership in organizations (6 $6^{\text {th }}$ edn), Englewood Cliffs, NJ: Prentice Hall. 